\title{
In vitro Nutritional Evaluation of Concentrates Containing Different Levels of Duckweed Supplementation as Protein Source for Ruminants
}

\author{
K. Subbaiah ${ }^{1}$, J. S. Lamba ${ }^{*}$, Jasmine Kaur ${ }^{1}$, Sandeep Kaswan $^{2}$, \\ M.D. Ansal ${ }^{3}$ and R.S. Grewal ${ }^{1}$
}

${ }^{1}$ Department of Animal Nutrition, College of Veterinary Science, Guru Angad Dev Veterinary and Animal Science University, Ludhiana, Punjab, India

${ }^{2}$ Department of Livestock Production and Management GADVASU, Ludhiana, Punjab, India

${ }^{3}$ Department of Acquaculture, college of Fisheries, Guru Angad Dev Veterinary and Animal Sciences University, Ludhiana, Punjab, India

*Corresponding author

\section{A B S T R A C T}

The present study was undertaken to study the effect of varying levels of duckweed supplementation on in vitro utilization of concentrate mixtures replacing $1 / 3 \mathrm{CP}$ of soybean, $2 / 3 \mathrm{CP}$ and $100 \% \mathrm{CP}$ of soybean with duckweed. It was found that the net gas production was significantly decreased as the duckweed supplementation level increased in the concentrate ration. It was significantly higher in control and concentrate $2(1 / 3$ duckweed) and significantly lowest in concentrate 4 (100\% duckweed). The partition factor (PF) was significantly lowest in concentrate 2 followed by control and concentrate 3 (2/3 duckweed) and significantly higher in concentrate 4 (100\% duckweed). The OMD, NDFD \& True Digestibility was significantly higher in control but it was statistically comparable in duckweed supplemented concentrate ration. The MMP and EMMP was statistically comparable between control and $1 / 3$ duckweed supplemented concentrate but it was significantly higher in concentrate $4(100 \%$ duckweed $)$. The ME value was significantly lower in concentrate $4(100 \%$ duckweed) and statistically higher in control and $1 / 3$ duckweed concentrate rations. It can be concluded that duckweed meal can be replaced upto $1 / 3$ protein of soybean without any adverse effect.

\section{Introduction}

One of the most expensive costs to any livestock operation is feed. The feedstuffs included in livestock diets have direct effects on the cost of production. The protein component is a critical nutrient in ruminant rations. Protein is an expensive macronutrient. In the formulation of ruminant rations, amino acids supplied by protein play a key role. In all diet formulations, soybean meal (SBM) is the most widely used protein supplement. The amino acids present in SBM and the abundance of the feedstuff make it attractive as a universal protein source; however, soybean meal does raise the cost of the diet. One such feedstuff is duckweed, a tiny, free-floating, vascular aquatic plant. The 
aquatic plant duckweed can have similar crude protein levels and contains the essential amino acids needed ruminant rations. Studies have reported crude protein in duckweed as high as $45 \%$. The lipid content of duckweed can vary as low as 1.8-2.5 percent in duckweed species grown in nutrient-poor water to as high as 3-7 percent for duckweed grown in nutrient-rich water Duckweed has high quality protein with a superior amino acid profile than most plant proteins and is similar to animal protein (Rusoff et al., 1980). The nutrient composition value of duckweeds can be compared with that of alfalfa in terms of lysine and arginine. However, duckweeds are also rich in leucine, threonine, valine, isoleucine and phenylalanine (FAO 2009). Soybean meal contains $44 \%$ to $48 \%$ crude protein and is used extensively as a feedstuff. The goal of this research is to explore the nutritional quality of duckweed particular as the protein source in ruminants.

\section{Materials and Methods}

The duckweed sample used in the in vitro study was obtained from the department of fisheries, GADVASU, Ludhiana was air-dried and then ground in a Wiley mill through a $2 \mathrm{~mm}$ screen. The Four concentrate mixtures were prepared by using various duckweed levels i.e. Conc 1(control), Conc 2(1/3 duckweed), Conc 3 (2/3 duckweed) and Conc 4 (100\% duckweed) replacing the total CP of soybean in 50: 50 ratio ( $\mathrm{R}: \mathrm{C}$ ) as shown in Table 1. All the concentrate mixtures prepared were iso-nitrogenous having approximately $20 \%$ CP. The samples were analysed for proximate (AOAC, 2000) and cell wall components (Robertson and Vansoest, 1981).

\section{Animal feeding and rumen analysis}

Rumen liquor was collected in morning (6 am) from fistulated animals before feeding and watering into a pre-warmed thermo-flask and brought to the laboratory. Donor animals were fed on basal diet (concentrate @ $3 \mathrm{~kg}$ and wheat straw ad libitum).

The in vitro gas production was done according to Menke et al., (1979). The amount of net gas produced (NGP) was used to calculate the metabolizable energy (ME) value. Neutral Detergent Fibre (NDF) of the residue was also determined. Total degradable sample (TDS), organic matter degradability (\% OMD), partition factor (PF), organic matter degradability (\% OMD), neutral detergent fiber degradability (\% NDFD), microbial biomass production (mg, MBP), efficiency of microbial mass production (\% EMMP), true digestibility (\% TD) and short chain fatty acids (mmol, SCFA) were calculated according to Makkar (2004). Volatile fatty acids (VFAs) were estimated by (Cottoyn and Boucque, 1968) using gas liquid chromatography (GLC) technique using Net Chrom-9100 model. The gas column $(6 \mathrm{ft}$ length and 1/8 inch diameter) packed with chromosorb 101 was used for the estimation of VFA. The gas flow for nitrogen hydrogen and zero air were 30,30 , and $320 \mu 1 / \mathrm{min}$, respectively. Temperature of injector oven, column oven and detector were $270^{\circ} \mathrm{C}, 172^{\circ} \mathrm{C}$ respectively.

\section{Statistical analysis}

Data found from in vitro study were analyzed 1x3 factorial design (Snedecor and Cochran, 1994), by using SPSS Version 19. The differences in means were tested by Tukey B.

\section{Results and Discussion}

The ingredient and chemical composition of different concentrates supplemented with varying levels of duckweed is given in Table 1 and 2. The CP content of control concentrate and duckweed supplemented concentrates varied from $20.14 \%$ to $20.74 \%$. All the 
concentrate rations prepared were isonitrogeneous in nature. The NDF content varied from $39.60 \%$ to $42.60 \%$. The fat content of ration was between $2.65 \%$ to $2.90 \%$. The ash content in control concentrate ration was $11.0 \%$ while in duckweed supplemented concentrates ration it varied from 14.20 to $19.35 \%$ and $\mathrm{OM}$ varied from $80.65 \%$ to $85.80 \%$ in duckweed supplemented concentrate ration and in control concentrate it was $89 \%$.The total carbohydrates (TCHO) in control concentrate ration was $66.23 \%$ while in duckweed concentrate mixtures it varied from 56.30 to $62.63 \%$. The non-fiber carbohydrates (NFC) of the duckweed supplemented concentrates varied from $14.25 \%$ to 21.43 and in control it was $26.63 \%$.

Concentrate mixtures containing different levels of replacement of $\mathrm{CP}$ of soybean with duckweed is shown in Table 3. The control concentrate mixture has significantly produced higher $(\mathrm{p}<0.05)$ net gas production $(89.50 \mathrm{ml})$ and lowest in $100 \%$ duckweed based concentrate mixture $(70.50 \mathrm{ml})$. However, the $1 / 3$ duckweed concentrate produced $(85.83 \mathrm{ml})$ and $2 / 3$ duckweed concentrate $(74.16 \mathrm{ml})$. There were significant effect on TDS and partition factor in the concentrate ration. The truly degraded substrate was statistically comparable in 2/3 (304.81 $\mathrm{mg})$ and $100 \%$ duckweed concentrate mixture $(302.87 \mathrm{mg})$. The partitioning factor $(\mathrm{PF})$ is the ratio of organic matter degraded (mg) in vitro to the volume of gas $(\mathrm{ml})$ produced. A higher partitioning factor means that proportionally more of the degraded matter is incorporated into microbial mass i.e. the efficiency of microbial protein synthesis is higher. The partition factor calculated in vitro provides useful information for predicting the dry matter intake, microbial mass production in the rumen and the methane emission of the whole ruminant animal. The $\mathrm{PF}$ value was statistically higher in $100 \%$ duckweed (3.42) and lowest in $1 / 3$ duckweed concentrate mixture (3.05). The organic matter digestibility was statistically higher in control concentrate mixture $(86.22 \%)$ and it was statistically comparable in all duckweed containing concentrate mixtures as it varied from $79.00 \%$ to $80.78 \%$ ). There were no statistically significant differences has been seen on neutral detergent fiber digestibility (NDFD\%). It varied from 58.95\% (100\% duckweed concentrate mixture) to $69.02 \%$ (control concentrate mixture). The efficiency of microbial mass production was significantly higher $(\mathrm{p}<0.05)$ in $100 \%$ duckweed based $(62.20 \%)$ and lowest in control rations $(47.21 \%)$. However, it was statistically comparable in control and $1 / 3$ duckweed concentrate mixture. There were statistically significant higher difference in true digestibility in control $(86.66 \%)$ and duckweed containing concentrate mixture. The control concentrate ration has produced significantly higher $(\mathrm{p}<0.05)$ short chain fatty acids (1.06 mmole), followed by $1 / 3$ duckweed based ration $(1.00 \mathrm{mmole})$ and lowest SCFA was seen in $100 \%$ duckweed based rations $(0.83 \mathrm{mmole})$. The $\mathrm{pH}$ value was significantly higher (6.85) in urea rations and lowest was observed in SRU based rations. The 1/3duckweed based concentrate rations had significantly higher $(\mathrm{p}<0.05)$ ammonia concentration $(36.51 \mathrm{mg} / \mathrm{dl})$ and lowest in control concentrate $(29.16 \mathrm{mg} / \mathrm{dl})$. However it was statistically comparable in $2 / 3$ and $100 \%$ duckweed concentrate and also between $1 / 3$ and 2/3 duckweed concentrate mixtures. Metabolizable energy (ME) was statistically comparablein $100 \%$ and 2/3 duckweed based concentrate mixtures and between control and $1 / 3$ duckweed concentrate mixture rations. The amount of fermentable methane $(0.531 \mathrm{mmol})$ was lower $(\mathrm{p}<0.05)$ in control and higher in $100 \%$ duckweed $\{0.574 \mathrm{mmol}\}$ based rations, whereas fermentable carbon dioxide was significantly higher $(\mathrm{p}<0.05)$ in control $(0.251 \mathrm{mmol})$ and lowest in $2 / 3$ duckweed based rations $(0.227 \mathrm{mmole})$ (Fig. $1)$. 
Fig.1 Chemical composition of concentrates fed to male goats, \% DM basis

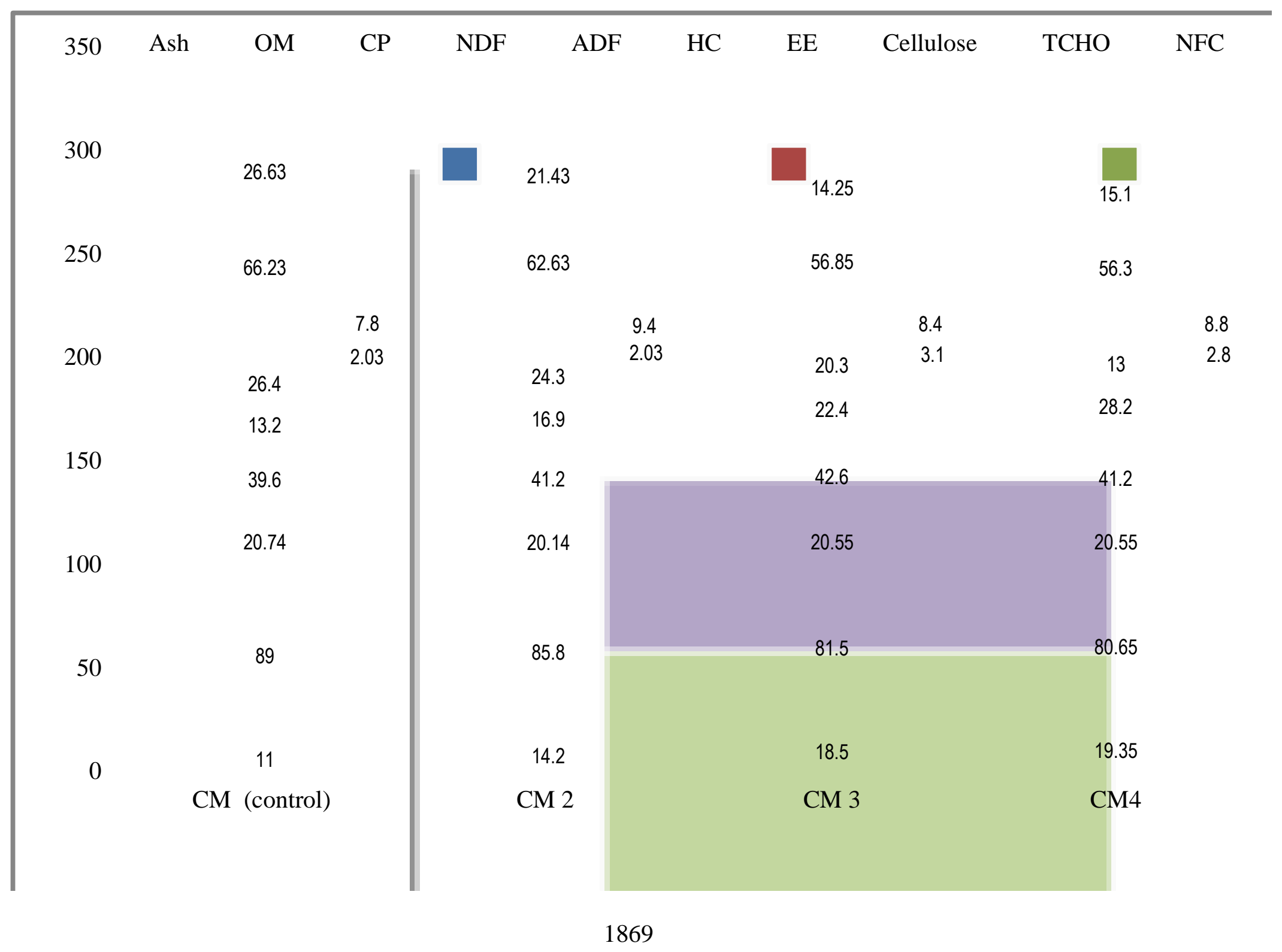


Table.1 Ingredient composition of different concentrate mixtures containing duckweed

\begin{tabular}{|l|c|c|c|c|}
\hline Ingredient & Control & $\mathbf{1 / 3}$ duckweed & $\mathbf{2 / 3}$ duckweed & $\mathbf{1 0 0 \%}$ duckweed \\
\hline Maize & 35 & 35 & 35 & 35 \\
\hline Soybean & 28 & 18.6 & 9.3 & 0 \\
\hline Duckweed & 0 & 15.5 & 31 & 46 \\
\hline Wheat bran & 17 & 13 & 8 & 4 \\
\hline Rice bran & 14.75 & 12.6 & 11.5 & 2 \\
\hline Mineral Mixture & 2 & 2 & 2 & 1 \\
\hline Salt & 1 & 1 & 1 & 1 \\
\hline Urea & 0 & 0.3 & 0.7 & 1.5 \\
\hline Bypass fat & 2.25 & 2 & 1.5 & \\
\hline
\end{tabular}

Table.2 Chemical composition of concentrates fed to male goats, \% DM basis

\begin{tabular}{|l|c|c|c|c|}
\hline Parameters & $\begin{array}{c}\text { Concentrate } \\
\text { Mixture(control) }\end{array}$ & $\begin{array}{c}\text { Concentrate } \\
\text { Mixture 2 }\end{array}$ & $\begin{array}{c}\text { Concentrate } \\
\text { Mixture 3 }\end{array}$ & $\begin{array}{c}\text { Concentrate } \\
\text { Mixture 4 }\end{array}$ \\
\hline DM & 92 & 92 & 91 & 91 \\
\hline Ash & 11.0 & 14.2 & 18.5 & 19.35 \\
\hline OM & 89 & 85.8 & 81.50 & 80.65 \\
\hline CP & 20.74 & 20.14 & 20.55 & 20.55 \\
\hline NDF & 39.6 & 41.2 & 42.6 & 41.2 \\
\hline ADF & 13.2 & 16.9 & 22.4 & 28.2 \\
\hline HC & 26.40 & 24.30 & 20.3 & 13.0 \\
\hline EE & 2.65 & 2.70 & 2.90 & 2.80 \\
\hline Cellulose & 7.8 & 9.4 & 8.4 & 8.80 \\
\hline TCHO & 66.23 & 62.63 & 56.85 & 56.30 \\
\hline NFC & 26.63 & 21.43 & 14.25 & 15.10 \\
\hline
\end{tabular}

Table.3 In-vitro utilization of nutrients of concentrate mixtures containing different levels of duckweed

\begin{tabular}{|l|c|c|c|c|c|}
\hline Parameters & Concentrate 1 & Concentrate2 & Concentrate 3 & Concentrate 4 & SEM \\
\hline NGP, ml & $89.00^{\mathrm{c}}$ & $86.00^{\mathrm{c}}$ & $74.00^{\mathrm{b}}$ & $70.00^{\mathrm{a}}$ & 3.02 \\
\hline TDS, mg & $330.19^{\mathrm{d}}$ & $325.18^{\mathrm{c}}$ & $304.81^{\mathrm{b}}$ & $302.87^{\mathrm{a}}$ & 4.56 \\
\hline PF & $3.19^{\mathrm{b}}$ & $3.05^{\mathrm{a}}$ & $3.25^{\mathrm{b}}$ & $3.42^{\mathrm{c}}$ & 0.051 \\
\hline OMD, \% & $86.22^{\mathrm{b}}$ & $80.78^{\mathrm{a}}$ & $79.00^{\mathrm{a}}$ & $79 . .03^{\mathrm{a}}$ & 1.16 \\
\hline NDFD, \% & $69.02^{\mathrm{b}}$ & $59.97^{\mathrm{a}}$ & $59.83^{\mathrm{a}}$ & $58.95^{\mathrm{a}}$ & 1.68 \\
\hline MMP, mg & $134.39^{\mathrm{a}}$ & $135.98^{\mathrm{a}}$ & $142.01^{\mathrm{a}}$ & $148.87^{\mathrm{b}}$ & 2.31 \\
\hline EMMP,\% & $47.21^{\mathrm{a}}$ & $51.77^{\mathrm{a}}$ & $58.98^{\mathrm{b}}$ & $62.20^{\mathrm{b}}$ & 2.39 \\
\hline TD,\% & $86.66^{\mathrm{b}}$ & $81.40^{\mathrm{a}}$ & $79.14^{\mathrm{a}}$ & $80.16^{\mathrm{a}}$ & 1.13 \\
\hline SCFA, mmole & $1.06^{\mathrm{d}}$ & $1.00^{\mathrm{c}}$ & $0.87^{\mathrm{b}}$ & $0.83^{\mathrm{a}}$ & 0.028 \\
\hline pH & $6.61^{\mathrm{a}}$ & $6.77^{\mathrm{b}}$ & $6.97^{\mathrm{d}}$ & $6.86^{\mathrm{c}}$ & 0.02 \\
\hline ME, MJ/kg DM & $10.20^{\mathrm{c}}$ & $10.13^{\mathrm{c}}$ & $7.07^{\mathrm{b}}$ & $6.68^{\mathrm{a}}$ & 0.46 \\
\hline NH3-N, mg/dl & $29.16^{\mathrm{a}}$ & $36.51^{\mathrm{d}}$ & $36.18^{\mathrm{c}}$ & $35.88^{\mathrm{b}}$ & 0.003 \\
\hline Ferm. $\mathrm{CO}_{2, \mathrm{mmol}}$ & $0.251^{\mathrm{d}}$ & $0.239^{\mathrm{c}}$ & $0.227^{\mathrm{a}}$ & $0.236^{\mathrm{b}}$ & 0.003 \\
\hline Ferm. $\mathrm{CH}_{4, \mathrm{mmol}}$ & $0.531^{\mathrm{a}}$ & $0.553^{\mathrm{b}}$ & $0.572^{\mathrm{c}}$ & $0.574^{\mathrm{d}}$ & 0.006 \\
\hline
\end{tabular}

Means bearing different superscripts in a row differ significantly $(\mathrm{P}<0.05)$ 
Table.4 In vitro volatile fatty acids production $(\mathrm{mM} / \mathrm{dl})$ of different concentrates containing different levels of duckweed

\begin{tabular}{|l|c|c|c|c|c|}
\hline Parameters & Conc 1 & conc 2 & Conc 3 & Conc4 & sem \\
\hline Acetic acid & $4.22^{\mathrm{b}}$ & $4.87^{\mathrm{d}}$ & $3.75^{\mathrm{a}}$ & $4.79^{\mathrm{c}}$ & 0.173 \\
\hline Propionic acid & $2.03^{\mathrm{c}}$ & $2.13^{\mathrm{d}}$ & $1.53^{\mathrm{a}}$ & $1.93^{\mathrm{b}}$ & 0.085 \\
\hline Iso butyric acid & $0.030^{\mathrm{a}}$ & $0.056^{\mathrm{d}}$ & $0.042^{\mathrm{b}}$ & $0.052^{\mathrm{c}}$ & 0.004 \\
\hline Butyric acid & $0.62^{\mathrm{b}}$ & $0.67^{\mathrm{d}}$ & $0.47^{\mathrm{a}}$ & $0.65^{\mathrm{c}}$ & 0.028 \\
\hline Iso valeric acid & $0.086^{\mathrm{b}}$ & $0.116^{\mathrm{d}}$ & $0.085^{\mathrm{a}}$ & $0.095^{\mathrm{c}}$ & 0.005 \\
\hline Valeric acid & 0.00 & 0.00 & 0.0 & 0.00 & 0.000 \\
\hline TVFA & $6.98^{\mathrm{b}}$ & $7.85^{\mathrm{d}}$ & $5.88^{\mathrm{a}}$ & $7.52^{\mathrm{c}}$ & 0.282 \\
\hline Relative proportion & $\%$ & & & & \\
\hline Acetate & $60.37^{\mathrm{a}}$ & $62.11^{\mathrm{b}}$ & $63.73^{\mathrm{c}}$ & $63.80^{\mathrm{c}}$ & 0.53 \\
\hline Propionate & $29.01^{\mathrm{d}}$ & $27.12^{\mathrm{c}}$ & $25.99^{\mathrm{b}}$ & $25.62^{\mathrm{a}}$ & 0.49 \\
\hline Iso butyrate & $0.43^{\mathrm{a}}$ & $0.72^{\mathrm{c}}$ & $0.71^{\mathrm{bc}}$ & $0.69^{\mathrm{b}}$ & 0.045 \\
\hline Butyrate & $8.94^{\mathrm{d}}$ & $8.56^{\mathrm{b}}$ & $8.13^{\mathrm{a}}$ & $8.60^{\mathrm{c}}$ & 0.11 \\
\hline Isovalerate & $1.24^{\mathrm{a}}$ & $1.48^{\mathrm{d}}$ & $1.44^{\mathrm{c}}$ & $1.27^{\mathrm{b}}$ & 0.039 \\
\hline Valerate & 0.00 & 0.00 & 0.00 & 0.00 & 0.00 \\
\hline A:P ratio & $2.08^{\mathrm{a}}$ & $2.28^{\mathrm{b}}$ & $2.45^{\mathrm{c}}$ & $2.49^{\mathrm{d}}$ & 0.061 \\
\hline
\end{tabular}

Means bearing different superscripts in a row differ significantly $(\mathrm{P}<0.05)$

The effect of different concentrate mixtures containing different levels of duckweed containing on total and individual volatile fatty acids in vitro is presented in (Table 4). The TVFA was significantly lowest $(\mathrm{p}<0.05)$ in $2 / 3$ duckweed $(5.88 \mathrm{mM} / \mathrm{dl})$ and was significantly higher in $1 / 3$ duckweed based concentrate mixture $(7.85 \mathrm{mM} / \mathrm{dl})$. The relative percent of acetate was significantly lowest $(60.37 \%)$ in control concentrate mixture and highest in $2 / 3$ duckweed $(63.73 \%)$ and $100 \%$ duckweed concentrate mixture $(63.80 \%)$. The propionate percent was statistically higher in control concentrate $(29.01 \%)$ and lowest in $100 \%$ duckweed based concentrate mixture $(25.62 \%)$. The percent isobutyric was significantly higher $(p<0.05)$ in $2 / 3$ duckweed concentrate mixture $(0.72 \%)$ whereas it was significantly lower in control concentrate $(0.43 \%)$. The butyrate percent was observed to be highest in control concentrate ration $(8.94 \%)$ followed by $1 / 3$ duckweed $(8.56 \%)$ and $100 \%$ duckweed based concentrate ration $(8.60 \%)$ and lowest percent in $2 / 3$ duckweed based concentrate mixture $(8.13 \%)$. The isovalerate percent was significantly higher in $1 / 3$ duckweed (1.24\%) and lowest in control concentrate mixture $(0.87 \%)$. The acetate to propionate ratio was significantly lowest $(\mathrm{p}<0.05)$ in control $(2.08)$ and highest in 100 5duckweed based concentrate mixture (2.49).

The net gas production was significantly decreased as the duckweed supplementation level increased in the concentrate ration. It was significantly higher in control and concentrate 2 and significantly lowest in concentrate 4 (100\% duckweed). The partition factor (PF) was significantly lowest in concentrate $2(1 / 3$ duckweed) followed by control and concentrate 3(2/3 duckweed) and significantly higher in concentrate $4(100 \%$ duckweed). The OMD was significantly higher in control but it was statistically comparable in duckweed supplemented concentrate rations. The NDFD was significantly higher in control concentrate 
ration but statistically comparable in duckweed supplemented concentrate rations. The MMP and EMMP was statistically comparable between control and $1 / 3$ duckweed supplemented concentrate ration 2 but it was significantly higher in concentrate $4(100 \%$ duckweed). The true digestibility was significantly higher in control but statistically comparable between duckweed supplemented concentrate rations. The ME value was significantly lower in concentrate $4(100 \%$ duckweed) and statistically higher in control and $1 / 3$ duckweed concentrate rations. It can be concluded that duckweed meal can be replaced upto $1 / 3$ protein of soybean without any adverse effect.

\section{References}

Association of official Analytical chemists (AOAC). 2000. Official Methods for Analysis $17^{\text {th }}$ ed. AOAC International, Gaithersburg, MD.

Cottyn B G and Boucque C V. 1968. Rapid methods for the gas chromatographic determination of volatile acids in rumen fluid. Journal of Agricultural Food Chemistry 16: 105-107.

Food and Agriculture organization of the United Nations (FAO). 2009. Use of algae and aquatic macrophytes as feed in small-scale aquaculture. A review
Makkar, H.P.S. 2004. Recent advances in the in vitro gas method for evaluation of nutritional quality of feed resources. In: Assessing Quality and Safety of Animal Feeds. FAO Animal Production and Health Series 160. FAO, Rome, pp. 5588

Menke K H, Raab L, Salewski A, Steingass H, Fritz D and Scheinder W. 1979. The estimation of the digestibility and metabolizable energy content of ruminant feed stuffs from the gas production when they are incubated with rumen liquor in vitro. Journal of Agriculture Science Cambridge 92: 217-222.

Robertson J A and P J Van Soest (1981). The Detergent system of analysis and its application to human food. In: The Analysis of dietry Fiber in Food (Ed W $\mathrm{P} \mathrm{T}$ James and $\mathrm{O}$ Theander). Marcel Dekker Inc., New York, pp. 123-158.

Rusoff, LL, Zeringue SP, Achacaso A S and Culley Jr D D. 1978. Feeding value of duckweed (an aquatic plant, family Lemnaceae) for ruminants. Journal of Dairy Science 61:186 (Supl. 1).

Snedecor G W and Cochran W G. 1994. Statistical Methods, 11th Edn. The Iowa State University Press, Ames, IA, p. 267.

\section{How to cite this article:}

Subbaiah, K., J.S. Lamba, Jasmine Kaur, Sandeep Kaswan, M.D. Ansal and Grewal, R.S. 2018. In vitro Nutritional Evaluation of Concentrates Containing Different Levels of Duckweed Supplementation as Protein Source for Ruminants. Int.J.Curr.Microbiol.App.Sci. 7(04): 18661872. doi: https://doi.org/10.20546/ijcmas.2018.704.213 